\title{
The Effectiveness of Using i-Spring Learning Medium to Improve the Activity and Students' Learning Outcomes
}

\author{
A. Mushawwir Taiyeb, Irma Suryani, Wahyu Hasanuddin \\ Department of Biology Faculty of Mathematics and Natural Science \\ UniversitasNegeri Makassar \\ Makasar, Indonesia \\ mtaiyeb333@gmail.com
}

\begin{abstract}
This study aimed to determine the increased activity of learning and learning outcomes in digestive system materials by the means of I-Spring learning medium. This research is a Classroom Action Research. The subjects were 31 students of class XI SMA Negeri 1 Enrekang South Sulawesi Province onthe second semester of academic year 2015/2016. The implementation of the action research consisted of two cycles, each cycle consisting of three meetings. The data wereobtained using observation sheet for learning activities and achievement test for learning outcomes. The data were analyzed using descriptive analysis. The results of the first cycle to the second cycle showed an increase in activity and learning outcomes. The average activity of students in the first cycle was $51.3 \%$ and the second cycle was $\mathbf{7 6 . 8 \%}$. The percentage of completeness student learning outcomes in the first cyclewas $70.6 \%$ and the second cycle increased to $78.5 \%$. Based on the results of this study, it can beconcluded that the application of learning using "ISpring" medium increased the activity and students' learning outcomes for class XI SMA Negeri 1 Enrekang on thematerialofDigestive System.
\end{abstract}

Keywords-Digestive System, Ispring Medium, Learning Activity, Learning Outcomes

\section{INTRODUCTION}

Education is a form of human who is responsible for the welfare of society and the country. As with any other countries, Indonesia is constantly doing a variety of efforts in improving the quality of education. These efforts include curriculum changes, repair facilities, enhancement of human resources [1].

At the beginning ofthe history of education, the teacher is the sole source for acquiringlessons. In a further development, learning resource that increases with the presence of the book. The writing of the book was based on a basic concept that there is something in the root of the human mind, without first through sensing. Where educators are starting to realize the need for a learning toolthat can provide stimulation and learning experience thoroughly to students through all the senses by using media [2].

The medium can be defined as the provid error occurrence of introductory communication from sender towards the receiver. The media is one of the components of acommunication, i.e. as a bearer of a message from the Communicator heading communication. Based on this definition, it can be said that the process of learning is the process of communication [3].

In recent years, the utilization of information and communication technology in education have already begun spread, ranging from the level of basic education, secondary, got to College, though variations and focus its utilization varies at each institution. Some schools already equip themselves with information and communication technology to support teaching and learning.

Advances in information communication technologies have also allows make use of various types of media at the same time in the form of multimedia learning. The use of interactive multimedia that includes audio-visual components for the delivery of the learning material can attract the attention of the students to learn. Interactive multimedia can also provide an opportunity to the students to do experiments and explorations so as to give all a learning experience rather than merely hear explanations of the teacher. The goal is to provide convenience and broader opportunities to students in the learning process.

Attendance and progress of information and communication technology in an era of global communications today has provided opportunities and expanding the interaction between teachers and students, between students and fellow learners, between the learners and the learning resources can happen anytime and anywhere without being limited by time and space. In addition, with the help of information and communication technology the process of delivery and presentation of learning material or idea can be more interesting and fun. On the other hand, the presence of information and communication technologies as new technologies provide challenges to teachers to be able to master it so you can select and utilize information and communication technologies effectively and efficiently in the teaching and learning process.

According [4], Various efforts have been undertaken by the world of education to improve the quality of education especially quality of learning through the utilization of information communication technologies. In addition to its 
function as a tool of human problem solving, information communication technology can also be utilized to support the learning process that is believed tobe: (1) improve the quality of learning, (2) expand access to education and learning, (3) reduce education costs, (4) answermust participate ininformation communication technologies and (5) develop skills in information communication technologies skills required when students work and in his life later.

The strategy of the utilization of information communication technologies in learning include: (1) information communication technologies as a tool or medium of learning, (2) information communication technologies as a means for learning, (3) information communication technologies as a source of learning, and (4) information communication technologies as a means of increased professionalism.

Multimedia interactive learning media developmentis learning that is simultaneously capable of displaying text, images, graphics, sound, video oranimation. Multimedia interactive learningis also one of the tools to create a more varied learning. Skills developed the media is one of the basic skills of teachers. Development of multimedia interactive learning can use computer programs. The difficulties commonly found in school is the lack of teacher skills in using software applications or programming in the making of the multimedia interactive learning, but it can be overcome by using a program that creates an ease in the manufacturing process without the need for computer skills and one of them is the power point program. Power point programs is one of the programs of Microsoft office software that has a lot of advantages making it suitable to be developed in to a multimedia interactive learning.

I-Spring Presenter is one of the tools that change the presentation file into flash and SCORM/AICC forms, i.e. Forms commonly used in learning with e-learning Learning management System. iSpring softwareis available in a free version and paid. I-Spring Presenter can easily be integrated in Microsoft power point so that its use does not require complicated skills. Some features of iSpring Presenter is:

1. iSpring Presenter work as add ins for Power Point, Power Point files more engaging and interactive Flash based and can be opened in virtually any computer or platform.

2. Developed to support e-learning. iSpring Presenter can insert various forms of media, so that the resulting learning media will be more attractive, which are able to record and synchronize the video presenter, adding Flash and YouTube videos, import or record audio, add information presentation maker and the company's logo, as well as making the navigation and unique design.

3. Easily distributed in flash format, which can be used anywhere and is optimized for the web.

Until then it's still a lot of teachers who are less interested in learning when teaching against the media before learners. Teachers rely solely on the method of speaking engagements, the assumption that there is that when the topic of learning or basic competencies was submitted orally, learner means already understand. In fact, it is precisely with oral course learners will be quickly forgotten so the information cannot be in here ntin its memory. Another case study with the media will facilitate more learners in capturing the concept so that the information obtained can be easily attached to the memory of the student.

\section{METHODS}

The research is Classroom Action Research that aims to find out the results of the study of biology students through the use of media of instruction iSpring. This study was conducted in a recurring cycle in which each cycle consists of four activities, namely, planning action, implementation measures, observation and reflection.

Factors of concern to researched is (1) learning activities where students are the result of biological observation and the observation sheets obtained from the students of Class XI MIA1 SMA Negeri 1 Enrekang, (2) the results of the study of biology students which is the value obtained by students of Class XI MIA1 SMA Negeri 1 Enrekang. On the material the digestive system through a written test that shows the level of understanding and mastery of the material.

The subject in this study are students of Class XI MIA1SMA Negeri 1 Enrekang listed on the 2015/2016 school year amounted to 31 students. This research was carried out on the even semester corresponds to the concept of the digestive system.

Technique of data analysis in this research are: 1) Student Learning Activities. The data were analyzed using student learning activities a descriptive qualitative analysis that is described with words or phrases to derive the conclusion made by seeing the results of observation on the observation sheet has been filled by the observer during the process of teaching and learning of each cycle, the way to measure student learning activities per item or per activity indicators then used the following formula. For the purposes of data analysis end of learning activities of students, then the frequencies of the first and second meetings on the first cycle of the average percentage wanted every student learning activities of students, later generalized in order to facilitate researchers in discussing how students with learning activities.

2) The Learning outcome. Data obtained from the results of the study of biology students of Class XI MIA SMAN 1 Enrekang analyzed quantitatively by using descriptive statistics.

Indicators of the success of this research are: 1) Learning activities. Indicators of the success of this research in terms of activity is in $60 \%$ of Biology learning activities students become ingredients of observation entered into the active category. 2) Learning outcome. This research is said to be successful if the results of the study of biology mean reaches $60 \%$ of students overall have reached Minimum Completeness Criterion (KKM) i.e. 75 .

\section{RESUlTS AND DiscussiON}

The results obtained from this study are analyzed qualitatively. Qualitative analysis is used to analyze the activity 
ofthe students and the learning outcomes of students in the learning process in the form of a percentage.

1) Analysis of the activity of the students during the learning process:

The results of research on student learning activities starting with the cycle I. Each cycle in this study consists of three meetings. Student learning activities that relate to the use of the iSpring medium was observed by using the observation sheet for each meeting and is composed of two observer, thateach observer watched the 16 students and 15 students. Observation sheet there are 7 components of the learning activities.

The table shows that the activity on the cycle I are at intervals of $35 \%-54 \%$ who belong to the category of less active, while based on the indicators of success, the standard category active students are at a minimum percentage of $60 \%$ so that the research should proceed to the next cycle.

TABLE I. FREQUENCY DISTRIBUTION OF ACTIVITY STUDENTS DURING THE LEARning PROCESS THROUGH THE APPLICATION OF THE ISPRING MEDIUM ON CYCLE I

\begin{tabular}{|c|c|c|c|c|c|c|}
\hline \multirow[b]{2}{*}{ No. } & \multirow[b]{2}{*}{ The observed components } & \multicolumn{5}{|c|}{ Cycle I } \\
\hline & & $I$ & II & III & $\begin{array}{c}\sum_{\text {Stud }} \\
\text { ents }\end{array}$ & $\%$ \\
\hline 1 & $\begin{array}{l}\text { Listen teacher's explanation (wh } \\
\text { en the students are } \\
\text { seen watching what the } \\
\text { teacher explained through the } \\
\text { media ISpring Suite } 6.2 \text { ) }\end{array}$ & 27 & 29 & 31 & 29 & 93.5 \\
\hline 2 & $\begin{array}{l}\text { Reading literature related learnin } \\
\mathrm{g} \text { materials provided }\end{array}$ & 16 & 18 & 20 & 18 & 58 \\
\hline 3 & $\begin{array}{l}\text { Ask a question (including hand- } \\
\text { picked with the intention } \\
\text { of wanting to ask) }\end{array}$ & 10 & 15 & 17 & 14 & 45.1 \\
\hline 4 & The given study materials noted. & 15 & 18 & 16 & 16 & 52.6 \\
\hline 5 & $\begin{array}{l}\text { Responding to a question } \\
\text { (give the answers } \\
\text { to the questions asked) }\end{array}$ & 5 & 5 & 7 & 5 & 18.2 \\
\hline 6 & $\begin{array}{l}\text { Ask for guidance teachers (when } \\
\text { student don't understand } \\
\text { answering the tasks) }\end{array}$ & 10 & 12 & 14 & 12 & 38.6 \\
\hline 7 & $\begin{array}{l}\text { Keep order in the process } \\
\text { of teaching and learning (not } \\
\text { playing, not interfere with } \\
\text { your friends, not noisy, not } \\
\text { out of the incoming class, etc.) }\end{array}$ & 17 & 15 & 18 & 16 & 53.7 \\
\hline \multicolumn{5}{|l|}{ Aver } & 15 & 51.3 \\
\hline
\end{tabular}

At Cycle II, a meeting was carried out three times. Cycle II shows an increase in the learning activities of students of Class XI MIA1 SMA Negeri 1 Enrekang. The percentage increase in the activity of learning from previous stages in the show in the Table II.

Table II shows an increase in the learning activities of the cycle I just of $51.3 \%$ to $78.8 \%$ in cycle II. The increase in the number of percentage of activity from cycle I to cycle II of $31.3 \%$. The increase has been entered into the active category. This shows the percentage of students reach the learning activities indicator of success that is a minimum of $60 \%$. So for category learning activities of students ended in cycle II.
TABLE II. FREQUENCY DISTRIBUTION OF ACTIVITY STUDENTS DURING The LEARning Process Through The APPLICATION OF THE I-SPRING MEDIUM ON CYCLE II

\begin{tabular}{|c|c|c|c|c|c|c|}
\hline \multirow[b]{2}{*}{ No. } & \multirow[b]{2}{*}{ The observed components } & \multicolumn{5}{|c|}{ Cycle I } \\
\hline & & $I$ & II & III & $\sum_{\text {Stud }}^{\sum_{\text {ents }}}$ & $\%$ \\
\hline 1 & $\begin{array}{l}\text { Listening to the teacher's } \\
\text { expalnation(when the } \\
\text { students are seen watching } \\
\text { what the } \\
\text { teacher explained through the } \\
\text { media ISpring Suite } 6.2 \text { ) }\end{array}$ & 29 & 31 & 31 & 30 & 97.8 \\
\hline 2 & $\begin{array}{l}\text { Reading literature related learnin } \\
\text { g materials provide }\end{array}$ & 25 & 27 & 25 & 25 & 82.7 \\
\hline 3 & $\begin{array}{l}\text { Asking a } \\
\text { question (including hand-picked } \\
\text { with the intention of wanting } \\
\text { to ask) }\end{array}$ & 20 & 23 & 27 & 23 & 75.2 \\
\hline 4 & The given study materials noted. & 27 & 27 & 29 & 27 & 89.1 \\
\hline 5 & $\begin{array}{l}\begin{array}{l}\text { Responding to a question } \\
\text { (give the }\end{array} \\
\text { answers } \\
\text { to the questions asked) }\end{array}$ & 10 & 16 & 20 & 15 & 49.4 \\
\hline 6 & $\begin{array}{l}\text { Asking for guidance teachers } \\
\text { (when student don't understand } \\
\text { it in answering the tasks) }\end{array}$ & 15 & 13 & 18 & 15 & 49.4 \\
\hline 7 & $\begin{array}{l}\text { Keeping order in the process } \\
\text { of teaching and learning (not } \\
\text { playing, not interfere with } \\
\text { your friends, not noisy, not } \\
\text { out of the incoming class, etc.) }\end{array}$ & 28 & 29 & 31 & 29 & 94.6 \\
\hline \multicolumn{5}{|c|}{ Average } & 15 & 51.3 \\
\hline
\end{tabular}

TABLE III. PERCENTAGE OF LEARNING ACTIVITIES OF STUDENTS During The LeARning Process Through The APPLiCATION OF The ISPRING MEDIUM

\begin{tabular}{|l|l|l|l|l|l|}
\hline \multirow{2}{*}{ Interval Value } & \multirow{2}{*}{ Category } & \multicolumn{2}{|c|}{ Frequency } & \multicolumn{2}{c|}{ Percentage (\%) } \\
\cline { 3 - 6 } & & $\begin{array}{c}\text { Cycle } \\
\boldsymbol{I}\end{array}$ & $\begin{array}{c}\text { Cycle } \\
\text { II }\end{array}$ & $\begin{array}{c}\text { Cycle } \\
\boldsymbol{I}\end{array}$ & $\begin{array}{c}\text { Cycle } \\
\text { II }\end{array}$ \\
\hline $85 \%-100 \%$ & very Active & 7 & 16 & 22.6 & 51.6 \\
\hline $65 \%-84 \%$ & Active & 8 & 4 & 25.8 & 12.9 \\
\hline $55 \%-64 \%$ & Fairly Active & 1 & 5 & 3.2 & 16.1 \\
\hline $35 \%-54 \%$ & Less Active & 0 & 4 & 0 & 12.9 \\
\hline $0 \%-34 \%$ & Not Active & 15 & 2 & 48.4 & 6.5 \\
\hline Total & & 31 & 31 & 100 & 100 \\
\hline
\end{tabular}

The results of observation learning activities of students during the learning process by using the media learning iSpring shows an increase from cycle I to cycle II. It is also supported by the opinions expressed by Hamalik (1986) [5] suggests that the use of the learning media in the process of teaching and learning can evoke desire and interest in the new, demotivating and evoking stimuli and learning activities, and even psychological influences brought against students. The use of media of instruction in the learning orientation will greatly help the effectiveness of the learning process and the 
delivery of the message and the content at that time. In addition to arousing the interest and motivation of students, learning media can also help students improve understanding, presenting interesting and reliable data, eases data interpretation, and condense information.

2) Analysis of the learning outcomes on the learning process:

The data results of the study of biology students of Class XI MIA1 SMA Negeri 1 Enrekang obtained through evaluation tests at the end of each cycle Administering the tests serve to measure the level of mastery of the students against the material that has been given. The results of each student's study analyzed quantitatively fed to the designation Criteria Minimum Completeness specified by the SMA Negeri 1 Enrekang

TABLE IV. PERCENTAGE LEARNING OUTCOME BIOLOGY STUDENTS OF CLASSXIIPA1SMAN1ENREKANGONCYCLE I AND CYCLE II

\begin{tabular}{|l|l|l|l|l|l|}
\hline \multirow{2}{*}{ Category } & \multirow{2}{*}{ Score } & \multicolumn{2}{|c|}{ Cycle I } & \multicolumn{2}{c|}{ Cycle II } \\
\cline { 3 - 6 } & & $\begin{array}{c}\text { Number } \\
\text { of } \\
\text { students }\end{array}$ & $\begin{array}{c}\text { Percentage } \\
(\%)\end{array}$ & $\begin{array}{c}\text { Number } \\
\text { of } \\
\text { students }\end{array}$ & $\begin{array}{c}\text { Percentage } \\
(\%)\end{array}$ \\
\hline $\begin{array}{l}\text { Not } \\
\text { Complete }\end{array}$ & $0-74$ & 15 & 48.4 & 12 & 38.7 \\
\hline Complete & $75-100$ & 16 & 51.6 & 19 & 61.3 \\
\hline Total & 31 & 100 & 31 & 100 \\
\hline
\end{tabular}

Based on the above table indicates that completeness students can study in cycle I of 31 students in class XI MIA1 SMA Negeri 1 Enrekang, there are 15 students who do not complete with the percentage of $48.3 \%$ and 16 students with percentages of $51.6 \%$ who achieve mastery category. While in cycle II, 31 of those students who do not complete decline amount i.e. from 15 students into 12 students with percentages of $38,7 \%$, so the percentage decrease occurred as much of $9.7 \%$ of $48.4 \%$ to $38.7 \%$. While students are thoroughly experienced an increased number of previously only 16 people, on cycle II increase the amount to 19 people. The number of percentages also increased by $51.6 \%$ to $61.3 \%$ previously only amounted to $51.6 \%$.

The percentage of the average value of the learning outcomes of students, on a cycle I $70.64 \%$ and cycle II experienced an increase of $7.9 \%$ to $78.54 \%$. The increase in student learning results obtained prove that the process of teaching and learning by using learning iSpring medium positively impact in improving student learning outcomes.

\section{CONCLUSION}

Based on research results, data analysis, and discussion, it can be summed up as follows:

1) Implementation of the medium learning, ISpring enhances the activity of learning in students of Class XI MIA1 SMA Negeri 1 Enrekang, i.e. of the 7 components of the observed activity are all experiencing an increase with the average percentage of $78.8 \%$.

2) Learning media use iSpring improve student learning outcomes at Class XI MIA1 SMA Negeri 1 Enrekang. This is evidenced by an increase in the category of complete learning students of $51.6 \%$ in cycle I became $61.3 \%$ in cycle II. The average value of the percentage of the results of the learning cycle I namely $70.6 \%$ while on cycle II percentage average of $78.5 \%$

Summary of research results in relation to the above, a suggestion that can be expressed by researchers is:

1) Before doing research using the media learning ISpring, should provide the first description of the model will be applied in the classroom, so that students are not confused when learning process begins.

2) Expected teacher can increase the confidence of students in each group so that learning can be run properly and in accordance with the target of research.

3) Expected to further research in order to develop and streng then the results of this research with advanced research on different materials or even on other subjects.

\section{REFERENCES}

[1] A. Webe, "Smart Teaching", JogjaBangkit Publisher: Yogyakarta, 2010.

[2] A. Sirodjuddin, "Development of learning media conception J", PendidikanPenabur: No.04/Th.IV/Juli 2008.

[3] Daryanto, "Learning Media The Role Is Very Important In Achieving Learning Objectives", Yogyakarta: Gava Media. D. D, 2013.

[4] E. Krisnadi, "Design of learning materials based information communication technologies", in workshop on developing learning materials based on information communication technolo-giesat Math and Science Faculty, State University of Yogjakarta, 2009.

[5] A. Arsyad, "Intructional Media", Jakarta: PT. Raja Grafindo Persada, 2016.

[6] D. Wulandari, "Development of multimedia interactive learning based on power point ISpring presenter on information and communication technology for senior high school. Padang, Universitas Bung Hatta. Volume 1 Nomor 1. http://ejurnal.bunghatta.ac.id/ index.php?journal, 2014.

[7] I.W. Santyasa, "The conceptual platform of learning media", In Workshop on Learning Media for High School Teachers, 2007. 